\title{
Customer Based Brand Equity for Empowering Sri Lanka as a Tourism Destination: With Special Reference to Tea Tourism
}

\author{
K. C. Koththagoda ${ }^{1}$ and S. C. Thushara ${ }^{2}$ \\ ${ }^{1}$ Department of Marketing Management, University of Kelaniya, Sri Lanka, Sri Lanka \\ ${ }^{2}$ Department of Commerce and Financial Management, University of Kelaniya, Sri Lanka \\ ${ }^{1}$ kosalackg@gmail.com, ${ }^{2}$ scthushara@gmail.com
}

\begin{abstract}
Tea tourism is one of the alternative forms of tourism which is being operated in the tea growing regions in the world. Sri Lanka also can benefit from adopting and promoting tea tourism. The main purpose of this study is to propose a practical model to empower Sri Lanka as a tea tourism destination. In this study, Keller's constructs of the pyramid of brand equity, including brand salience, brand performance, brand imagery, brand judgments, brand feelings, and brand resonance, are investigated and their relationships with brand equity, as well as their effects on customer loyalty and satisfaction in Tea tourism in Sri Lanka are determined. The statistical population of the present study is all foreign visitors from tea estates based recreational sites in Sri Lanka. The data were collected by administering questionnaire. The sample consisted with 385 randomly selected individuals. The research hypotheses were tested through structural equation modeling and the final model was confirmed. The findings of the study revealed that only the relationships between brand salience and customer loyalty, brand imagery and brand performance towards brand equity were not significant, and all other relationships were significant. Also, fit indices obtained from the conceptual model indicates that model is valid in explaining the relationships among variables to empower Sri Lanka as a Tea Tourism destination. Therefore this proposed model emphasized how marketers should design and implement the effective marketing programs to empower Sri Lanka as a tea tourism destination. In this way, Sri Lanka can be positioned as one of the attractive and more competitive tea tourism destinations in the world which in turn could make a positive impact on foreign exchange, employment oportunities and other economic factors.
\end{abstract}

Keywords: Tea Tourism, Brand Equity, Structural Equation Modelling, Sri Lanka Tourism

\section{Introduction}

The tourism indsutry is one of the largest and fastest growing industries in the world. According to the World Tourism Organization (UNWTO), in 2014, international tourist arrivals grew by $4.3 \%$ surpassing 1.133 billion arrivals. It has generated US\$ 1.5 trillion in export earnings from tourism and related activities 
(UNWTO, 2014). Further, UNWTO's Tourism 2020 Vision forecasts that international arrivals are expected to reach 1.6 billion by the year 2020 . Therefore in this context, destination marketing with new product development is one of the most important requirements to promote tourism in Sri Lanka. The world tourism industry has dynamically changed during past few decades and consequently tourism demand has conceptually changed into the adjectival tourism aspects as low impact tourism such as eco-tourism, sustainable tourism and other options such as cultural, art, extralegal, meditourism, adventure, extreme, natural, rural tourism apart from the mass tourism. Tea tourism is one of the most popular alternative types of tourism which is being operated all over the tea growing regions. Sri Lanka also possesses necessary requirements to be promoted and positioned in consumers' mind as a tea tourism destination. In practice, it is vital to analyze brand equity of a destination from the standpoint of the consumer and his or her perceptions of the location and it is important to policy makers and strategy markers to identify the customer based branding equity for the tourism destination before addressing dynamic branding strategy in order to be differentiated tourism destinations from all other competitors. Conseqiently, The main purpose of this study is to determine what role that the Keller's (2008) brand equity model can play in identifying the brand equity of Sri Lanka as a tea tourism destination and how it can be managed to gain the value through competitive advantage from customer satisfaction and customer loyalty to empower Sri Lanka as a tea tourism destination.

\section{Literature Review}

This Section reviews on literatures related to development of the conceptual framework of the study. Especially, this emphasized about Keller's (2008) brand equity model and previous studies on the customer satisfaction and customer loyalty in order to provide a strong literature support to formulate Hypotheses related to the Variables of conceptual framework.

\subsection{Brand Equity}

Building a strong brand involves creating brand equity. In common sense, brand equity is defined as the added value endowed by the brand to the product (Farquhar, 1989). In the last two decades, brand equity has become one of the most interesting research topics in marketing for both academics and practitioners. Despite the fact that brand equity is a potentially important marketing concept, it is not without controversy (Taylor, 2005). It is because brand equity is defined in different ways for different purposes (Keller, 1998). Brand equity is the most common tool used to represent brand performance (Pike, 2010) as it represents the added or subtracted value a brand offers to products or services (Aaker, 1996) and as such brand equity 
should reflect "the way customers think, feel, and act with respect to the brand"(Kotler and Keller, 2011).

\subsection{Customer Based Brand Equity}

The research made by Konecnik and Gartner (2007) on customer based brand equity for Slovenia is often mentioned in current brand equity literature as one of the influencial research on destination brand equity (Boo, Busser and Baloglu, 2009,). The research done by Boo et al. (2009) on customer-based brand equity for gambling destinations and the research carried out by Pike (2010) and Pike and Bianchi (2013) on customer-based brand equity for Australia and long and shorthaul markets are other examples of research in the field of destination brand equity.

Aaker (1991) defined "brand equity as a set of brand assets and liabilities linked to a brand, its name and symbol add to or subtract from the value provided by a product or service to a firm and/or that firm's customers." His approach to brand equity is viewed as a managerial and corporate strategy perspective. He stated that the assets and liabilities linked to a brand's name or symbol can be grouped into five dimensions: brand loyalty, brand awareness, perceived quality, brand associations, and other proprietary brand assets. Further it was suggested that brand equity can be generated and enhanced by strengthening those dimensions.

Recent definitions of brand equity have evolved and include the added value of name and expanded to a broad set of attributes that drives customer choice (Faircloth, Capella \& Alford, 2001). Faircloth et al. (2001) stated that "brand equity actually represents a product's position in the minds of consumers in the marketplace." Faircloth et al. (2001) proposed a conceptual model to operationalize brand equity and partially confirm the brand equity theory of Aaker (1991) and Keller (1993) which suggests that the brand equity can be enhanced by creating a positive brand image and brand attitude. They further suggested that positive brand image is a better predictor of brand equity than brand attitude and, enhances brand equity by increasing purchase intentions and willingness to pay premium prices. They recommended that the dimensions, the brand image and the brand attitude, or brand equity should be enriched and strengthened by brand equity management.

Today, the Customer Based Brand Equity (CBBE) model is a well-established marketing concept (Aaker, 1991, 1996; Keller, 1993, 2001). Keller (2008, 2009) extends the CBBE model in order to address the consumer knowledge structure behind the brand development and to reflect the relationship building process between customers and the brand. Specifically, the model reflects the CBBE pyramid (i.e. hierarchy) consisting of six brand building blocks corresponding to four stages of brand development. 
Keller (1998), who approached the concept of brand equity from the perspective of the consumer, defined "customer-based brand equity as the differential effect that brand knowledge has on the consumer or how customers respond to the marketing of that brand." He also suggested that as customers respond more favorably to a product whose brand is identified, the brand has positive customer-based brand equity and it exists when the consumer has a high level of awareness and familiarity and strong, favorable, and unique brand associations in their memory (Keller, 2001). The brand is established through the proper identity, the appropriate brand meaning, the right brand responses, and the appropriate brand relationships with customers by establishing six core brand values: brand salience, brand performance, brand imagery, brand judgments, brand feelings, and brand resonance (Keller, 2001).

The strongest brands do extremely well in all six of these areas and therefore achieve all four of the steps concerning building a brand. The top of the pyramid, consumer brand resonance, is considered the most valuable building block. This can only occur when all the other blocks are synchronized to fit the customers' needs and desires. A high consumer brand resonance means customers feel a loyalty towards the brand and continuously seek opportunities to interact with the brand and share this with others (Keller, 2001).

\subsection{Customer Loyalty and Customer Satisfaction}

According to Kotler (2005) and Kotler and Keller (2009) researches, the relationship between customer satisfaction and customer loyalty are very important and significant. Customer loyalty which is earned from the satisfaction of a particular product or service, can measures the volume or frequency of repurchase and recommend the product to others by the customer (Budiarty, Hawidjojo and Jomahir, 2013) .Customer satisfaction can be defined in different ways. Evaluating After goods and services purchasing, causes satisfaction from purchase. Overall, the researchers believe that customer satisfaction is one of the Key elements for repurchasing, customer word of mouth advertising and ultimately customer loyalty. Satisfied customers returns frequently for shopping or they will use services next time.

Loyalty, is measured by purchase intention, the tolerance level of prices of goods and services by customer and also offering goods and service to others. Customer loyalty is a deep and inner commitment that led to repurchase or reusing one product or service. Loyal customers are important to firms, even critical in that they are less price sensitive (Reichheld and Teal, 1996). Moreover, these customers are likely to purchase more frequently, try the firm's other product offerings and bring new customers to the firm (Reichheld \& Sasser, 1990). These customers play a 
major role in the firm's success and profitability (Eakuru \& Mat, 2008). Customer loyalty is measured by word-of-mouth, price insensitivity and purchase intentions (Bloemer and Odekerken-Schröder, 2002). Based on Aghaei, Mosavi, Vahediand Asadollahi (2013) developed a research model to describe the effect and relationship of constructs of brand equity from the viewpoint of Keller (2008) on customers' satisfaction and loyalty. Based on pervious literature evidences the current study proposes a model for developing strong brand equity from the perspective of customers for gaining competitive advantage from customer satisfaction and loyalty to empower Sri Lanka as a tea tourism destination. Specially Sri Lanka lacks marketing strategies and master plan to promote as a tourism destination. Thus Policy makers and marketers of Sri Lanka should focus more on practical approaches on this arena. Hence this research addresses the current situation while fulfilling the empirical knowledge gap.

\section{Conceptual Framework}

The conceptual model of the this study was designed using the constructs of brand equity (Keller, 2008) and considering two factors of customer satisfaction and brand loyalty how affecting to brand equity as extracted from the literature (Aghaei et al., 2013). This model is presented in Figure 01.

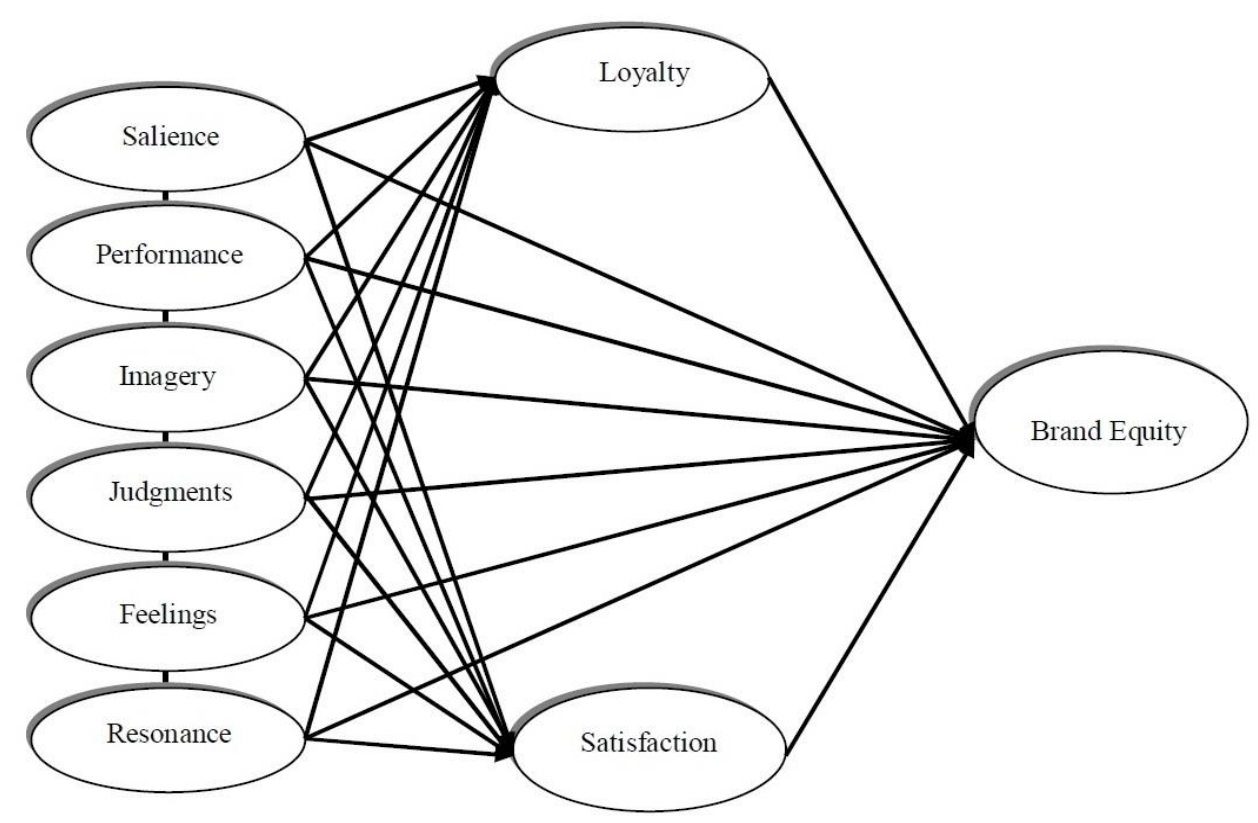

Figure 01: Conceptual Framework 
According to this model, the research hypotheses are as following:

H1: Resonance with brand, customers' feelings about brand, customers' judgments about brand, brand imagery, brand performance, and brand salience affect customers' satisfaction.

$\mathbf{H}_{2}$ : Resonance with brand, customers' feelings about brand, customers' judgments about brand, brand image, brand performance, and brand salience affect customers' loyalty to brand.

H3: Customers' satisfaction and loyalty affect brand equity.

H4: Resonance with brand, customers' feelings about brand, customers' judgments about brand, brand imagery, brand performance, and brand salience affect brand equity.

\section{Methodology}

For the purpose of data collecting adequate sample size was identified usually relevant annual population is ranged in a very high value though the population is unkonwn. Hence sample calculation with unknown population as adapted. The population of this study was tourist who visited tea estates based recreational sites in Sri Lanka. Since the population size was unspecified, Cochran's formula was used to calculate sample size. According to the calculation sample size was 385 . Random sampling technique was used to select the elements to the sample. Since this research is survey type research, data is collected with the use of astructured questionnaires. The questionnaire consists of 70 questions which is categorized into the ten. The sections were grouped based on questions related to the nine variables of the conceptual framework and general questions related to the demographic details of the respondents.

These nine variables are brand salience, brand performance, brand imagery, brand judgments, brand feelings, brand resonance, brand equity, customer satisfaction and loyalty. The first section is to measure the brand salience which defines how many times the brand is recalling by the customer during a purchases and consumption situations. The second section about brand performance and questions are focused on the product and its different abilities to satisfy customer needs such as financial needs and functional needs of the customer. Brand Imagery section is focused on the intangible attributes of the product. Consumer judgments focus upon customer's personal opinions and evaluations with regard to the brand. Consumer feelings section about exactly what it sounds like, the feelings that customers have towards a brand. Brand resonance section is to measure the bond that costumer has with the brand and his level of engagement. Other three sections were there to measure the 
overall brand equity, customer satisfaction and customer loyalty towards the destination. The variables were measured using 5-point Liker scale.

\subsection{Validity Test}

To evaluate the validity of these nine variables in measuring a principal component factor analysis with varimax rotation was performed. Decision making value for the Kaiser-Meyer-Olkin (KMO) should be greater than 0.5 Kaiser (1974) for the satisfactory analysis to proceed with and all the variables satisfied this precondition. The Bartlett's test of Sphericity is statistically significant at 5\% significance level and component matrix which was accepted which is higher than 0.3 . It satisfied all the decision making criteria.

\subsection{Reliability Test}

Reliability analysis measures how consistent results are yielded over time and across situations. Cronbach's alpha was applied to establish reliability (Zikmund, 2003). The least value acceptable for the reliability of the items was 0.7 (Lance, Butts, \& Michels) the alpha coefficient was calculated for each item. The results obtained refer to high reliability of the questionnaires as presented in Table 01 .

Table 01: Results of Estimating Cronbach's Alpha

\begin{tabular}{|l|c|c|}
\hline Variable & $\begin{array}{c}\text { Cronbach's alpha of } \\
\text { the sample }\end{array}$ & $\begin{array}{c}\text { Number of items for measuring } \\
\text { the construct }\end{array}$ \\
\hline Salience & 0.718 & Q10- Q13 \\
\hline Performance & 0.880 & Q14-Q26 \\
\hline Imagery & 0.817 & Q27-Q34 \\
\hline Judgment & 0.865 & Q35-Q45 \\
\hline Feelings & 0.703 & Q46-Q49 \\
\hline Resonance & 0.848 & Q50-Q59 \\
\hline Satisfaction & 0.711 & Q60-Q62 \\
\hline Loyalty & 0.712 & Q63-Q66 \\
\hline Brand Equity & 0.701 & Q67-Q70 \\
\hline
\end{tabular}

\subsection{Normality Test}

In this part of the study, Shapiro-Wilk test was utilized for determining the normality of data distribution.

H0: The relevant variable is normal.

H1: The relevant variable is not normal. 
Shapiro-Wilk test are below 01 and significant values are above 0.05 . The results of this test are presented in Table 2. Hence null hypothesis is accepted and data are assumed to be normally distributed. Another two tests are also performed to identify the normality behavior of the data distribution.

Table 02: Results of Kolmogorov-Smirnov and Shaprio Wilk Tests

\begin{tabular}{|l|r|r|r|r|r|r|}
\hline \multirow{2}{*}{} & \multicolumn{3}{|c|}{ Kolmogorov-Smirnov } & \multicolumn{3}{c|}{ Shapiro-Wilk } \\
\cline { 2 - 7 } & Statistic & \multicolumn{1}{c|}{ Df } & \multicolumn{1}{c|}{ Sig. } & \multicolumn{1}{c|}{ Statistic } & \multicolumn{1}{c|}{ df } & \multicolumn{1}{c|}{ Sig. } \\
\hline Brand & .090 & 385 & .000 & .986 & 385 & .060 \\
\hline Salience & .072 & 385 & .000 & .993 & 385 & .057 \\
\hline Performance & .036 & 385 & .200 & .996 & 385 & .493 \\
\hline Imagery & .043 & 385 & .087 & .994 & 385 & .162 \\
\hline Judgment & .056 & 385 & .006 & .992 & 385 & .065 \\
\hline Feelings & .058 & 385 & .003 & .989 & 385 & .670 \\
\hline Resonance & .043 & 385 & .078 & .996 & 385 & .419 \\
\hline Satisfaction & .072 & 385 & .000 & .991 & 385 & .058 \\
\hline Loyalty & .057 & 385 & .005 & .990 & 385 & .052 \\
\hline
\end{tabular}

\subsection{Method of Data Analysis}

In this study structural equation modeling was used as the method of data analysis. The assumption to be tested in a structural equation model is a causal relation among a set of unobserved constructs. These constructs are measured through a set of observed variables (Sarmad, Bazargan, Hejazi, 1999).Series of statically methods that allow complex relationships between one or more independent variables and one or more dependent variable is simply called as Structural equation modeling (SEM). In this study investigate the effect of six independent variables on three dependent variables which are related again as dependent and independent variables was measured in this research. Main purpose of this research is to develop a practical model with identified effective variables. For achieving this purpose structural equation modeling was used as the analyzing tool.

\section{Analysis and Discussion}

This section illustrates the results of statistical tests which have been performed in order to test hypotheses and confirm the final model. For hypotheses testing and acceptance criteria standard estimation values and $\mathrm{P}$ value which were generated from the model were used. For the evaluation probability with $95 \%$ confident level was used. Hence hypothesis were accepted which have a $\mathrm{P}$ value below 0.05. Standard estimation is the path coefficient of the relationship. Usually a path co- 
efficient above 0.1 (Wright, 1960) is the acceptance level of a hypothesis. The Structural equation model is shown with Figures 02 and 03 presenting P-values and Standard estimation respectively.

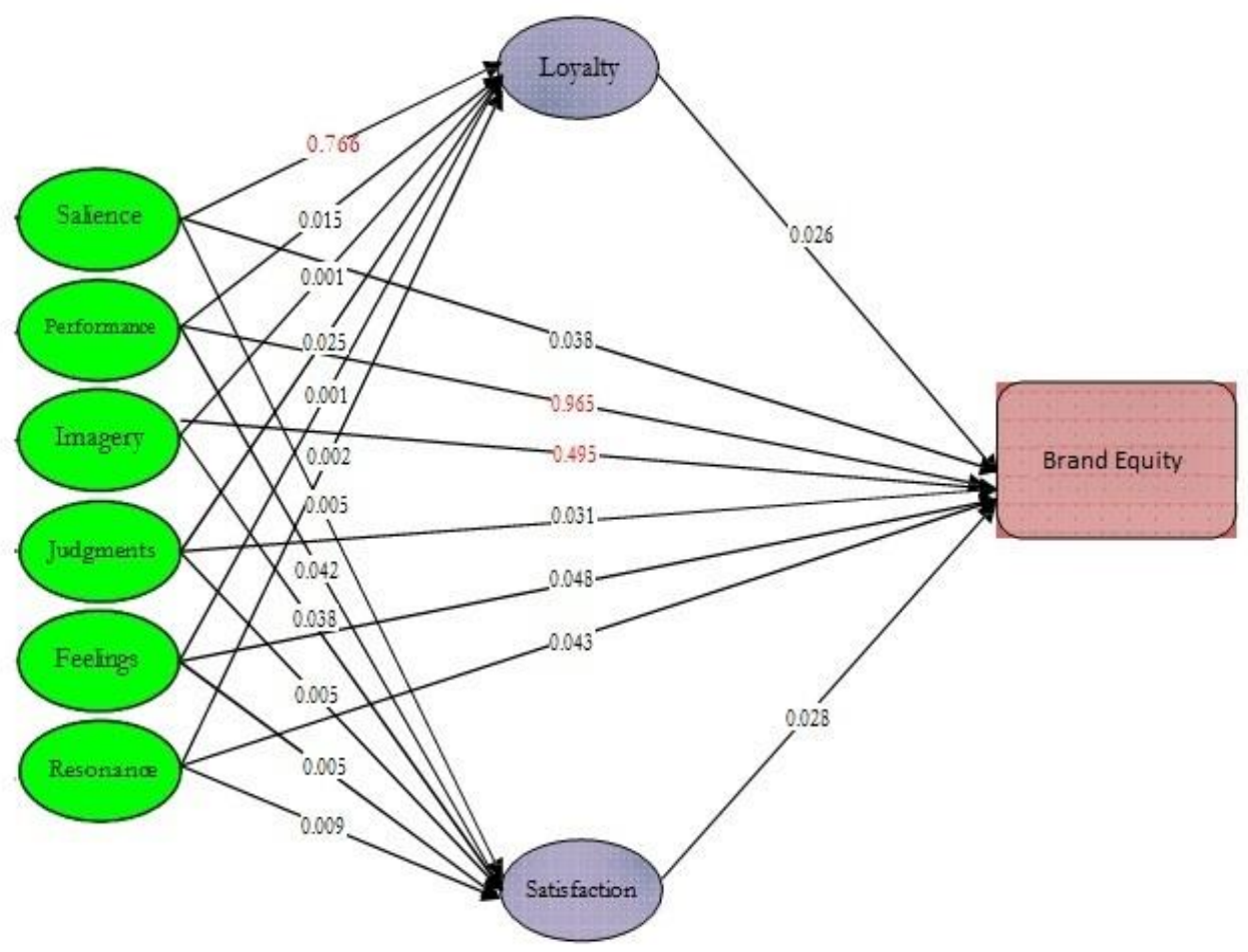

Figure 02: P - Values

As the results of path analysis in Table 03. indicate, brand salience, brand judgment, brand feeling, brand resonance are significant affected on brand equity with respect to the acceptance criteria of standard estimation above 0.1 and $\mathrm{P}$ value below 0.05 . But results reflect that brand performance and brand imagery do not significantly affect brand equity since standard estimation is below 0.1 and $\mathrm{P}$ value higher than 0.05 . 


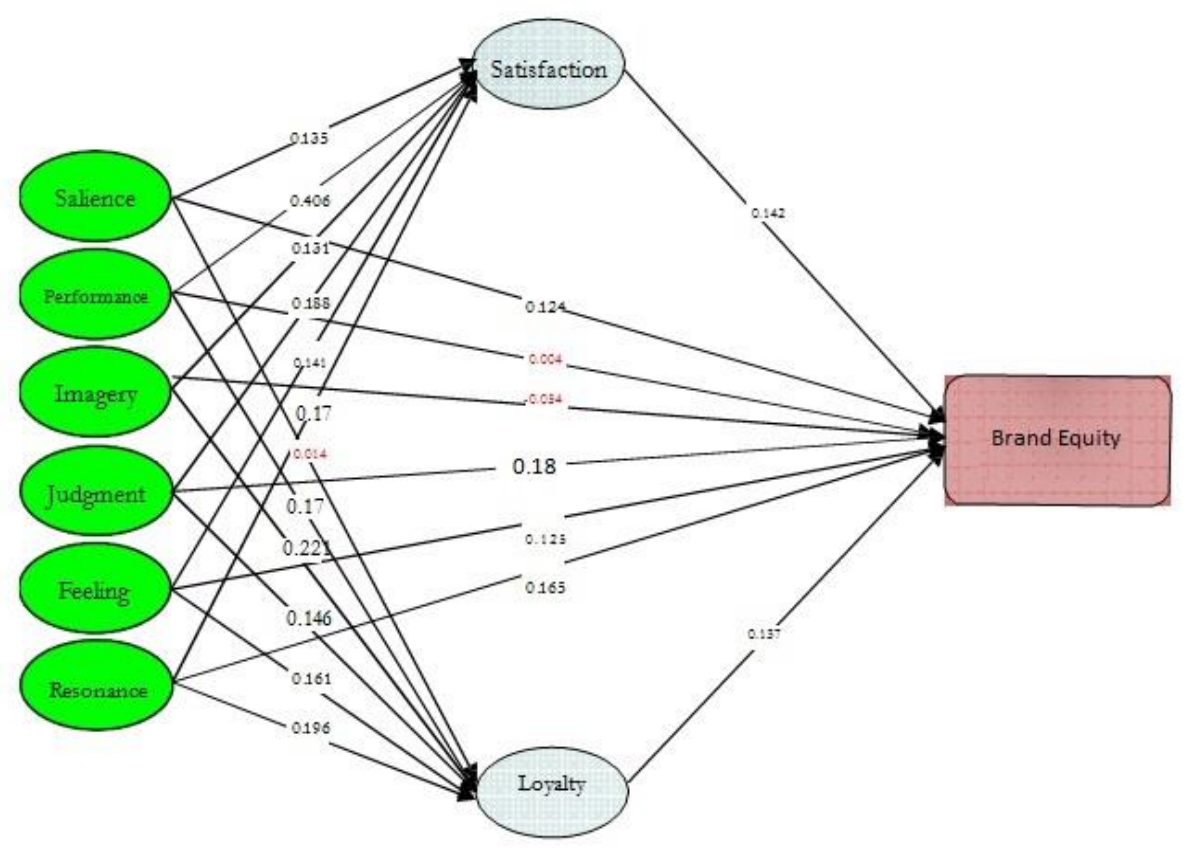

Figure 03: Standard Estimations

Table 03: The P- Values and Standard Estimation Values of the Final Model

\begin{tabular}{|l|l|l|c|c|c|}
\hline \multicolumn{2}{|c|}{ Direct Effect } & $\begin{array}{c}\text { Std. } \\
\text { Estimate }\end{array}$ & P-value & $\begin{array}{c}\text { Rejection or } \\
\text { Confirmation of } \\
\text { the Hypothesis }\end{array}$ \\
\hline Satisfaction & $<---$ & Salience & 0.135 & 0.005 & Confirmation \\
\hline Satisfaction & $<---$ & Performance & 0.146 & 0.042 & Confirmation \\
\hline Satisfaction & $<---$ & Imagery & 0.131 & 0.038 & Confirmation \\
\hline Satisfaction & $<---$ & Judgment & 0.188 & 0.005 & Confirmation \\
\hline Satisfaction & $<---$ & Feelings & 0.141 & 0.005 & Confirmation \\
\hline Satisfaction & $<---$ & Resonance & 0.170 & 0.009 & Confirmation \\
\hline Loyalty & $<---$ & Salience & 0.014 & 0.766 & Rejection \\
\hline Loyalty & $<---$ & Performance & 0.170 & 0.015 & Confirmation \\
\hline Loyalty & $<---$ & Imagery & 0.221 & 0.001 & Confirmation \\
\hline Loyalty & $<---$ & Judgment & 0.146 & 0.025 & Confirmation \\
\hline Loyalty & $<---$ & Feelings & 0.161 & 0.001 & Confirmation \\
\hline Loyalty & $<---$ & Resonance & 0.196 & 0.002 & Confirmation \\
\hline
\end{tabular}




\begin{tabular}{|l|l|l|c|c|c|}
\hline Brand Equity & $<---$ & Loyalty & 0.142 & 0.026 & Confirmation \\
\hline Brand Equity & $<---$ & Satisfaction & 0.137 & 0.028 & Confirmation \\
\hline Brand Equity & $<---$ & Salience & 0.124 & 0.038 & Confirmation \\
\hline Brand Equity & $<---$ & Performance & 0.004 & 0.965 & Rejection \\
\hline Brand Equity & $<---$ & Imagery & -0.054 & 0.495 & Rejection \\
\hline Brand Equity & $<---$ & Judgment & 0.180 & 0.031 & Confirmation \\
\hline Brand Equity & $<---$ & Feelings & 0.125 & 0.048 & Confirmation \\
\hline Brand Equity & $<---$ & Resonance & 0.165 & 0.043 & Confirmation \\
\hline
\end{tabular}

\subsection{Goodness of fit Indies}

There are many concepts have been develop to measure the model fitness of Structural equation modeling. For the proposed measurements levels and ranges of accepting have been proposed by various authors and researches (Schumacker \& Lomax, 2004).

Table 04: Model Fit Indies

\begin{tabular}{|c|c|c|}
\hline Model fit criterion & Accept & Interpretation \\
\hline Chi square & $\begin{array}{l}\text { Tabled x2 } \\
\text { value }\end{array}$ & $\begin{array}{l}\text { Compares obtained } \times 2 \text { value with } \\
\text { tabled value for given df }\end{array}$ \\
\hline $\begin{array}{l}\text { Goodness of fit index } \\
\text { (GFI) }\end{array}$ & $\begin{array}{l}0 \text { (no fit) to } 1 \\
\text { (perfect fit) }\end{array}$ & $\begin{array}{l}\text { Value close to } 0.9 \text { or } 0.95 \text { reflect a } \\
\text { good fit }\end{array}$ \\
\hline Adjusted GFI & $\begin{array}{l}0 \text { (no fit) to } 1 \\
\text { (perfect fit) }\end{array}$ & $\begin{array}{l}\text { Value adjusted for df, with } 0.9 \text { or } 0.95 \\
\text { a good model fit }\end{array}$ \\
\hline $\begin{array}{l}\text { Root mean square } \\
\text { residual (RMR) }\end{array}$ & $\begin{array}{l}\text { Researcher } \\
\text { defines level }\end{array}$ & $\begin{array}{l}\text { Indicates the closeness of } \Sigma \text { to } \mathrm{S} \\
\text { matrices }\end{array}$ \\
\hline Standardized RMR & $<0.05$ & $\begin{array}{l}\text { Value less than } 0.05 \text { indicates a good } \\
\text { model fit }\end{array}$ \\
\hline $\begin{array}{l}\text { Root mean square error } \\
\text { of approximation } \\
\text { (RMSEA) }\end{array}$ & $<0.05$ & Value of 0.05 to 0.08 indicate close fit \\
\hline $\begin{array}{l}\text { Tucker Lewis Index } \\
\text { (TLI) }\end{array}$ & $\begin{array}{l}0 \text { (no fit) to } 1 \\
\text { (perfect fit) }\end{array}$ & $\begin{array}{l}\text { Value close to } 0.9 \text { or } 0.95 \text { reflects a } \\
\text { good model fit }\end{array}$ \\
\hline Normed fit index (NFI) & $\begin{array}{l}0 \text { (no fit) to } 1 \\
\text { (perfect fit) }\end{array}$ & $\begin{array}{l}\text { Value close to } 0.9 \text { or } 0.95 \text { reflects a } \\
\text { good model fit }\end{array}$ \\
\hline $\begin{array}{l}\text { Parsimony fit index } \\
(\mathrm{PNFI})\end{array}$ & $\begin{array}{l}0 \text { (no fit) to } 1 \\
\text { (perfect fit) }\end{array}$ & $\begin{array}{l}\text { Compares values in alternative } \\
\text { models }\end{array}$ \\
\hline $\begin{array}{l}\text { Akaike information } \\
\text { criterion (AIC) }\end{array}$ & $\begin{array}{l}0 \text { (perfect) to } \\
\text { positive (poor) }\end{array}$ & $\begin{array}{l}\text { Compares values in alternative } \\
\text { models }\end{array}$ \\
\hline
\end{tabular}


Table 05: Summary of Model Fitness Values

\begin{tabular}{|l|l|c|c|}
\hline $\begin{array}{c}\text { Fitness } \\
\text { Criteria }\end{array}$ & Recommended Value & $\begin{array}{c}\text { Actual } \\
\text { Value }\end{array}$ & $\begin{array}{c}\text { Acceptance of Model } \\
\text { Fitness }\end{array}$ \\
\hline Chi square & Smaller Value & 1.310 & Accept \\
\hline GFI & $>0.95$ & 0.990 & Accept \\
\hline AGFI & $>0.95$ & 0.971 & Accept \\
\hline RMR & $<0.05$ & 0.029 & Accept \\
\hline RMSEA & $<0.05$ & 0.018 & Accept \\
\hline TLI & $>0.95$ & 0.999 & Accept \\
\hline NFI & 0 (poor) -1 (Fit) & 1.000 & Accept \\
\hline PNFI & 0 (poor) -1 (Fit) & 0.88 & Accept \\
\hline Hoelter & $>200$ & 1316 & Accept \\
\hline
\end{tabular}

According to the table it was indicated the good model fit with the data. It shows that the model identifies that factors affecting brand equity.

\subsection{Testing the Hypotheses}

\section{Testing the First Hypothesis:}

Resonance with brand, customers' feeling, customers' judgment about brand, brand imagery, brand performance and brand salience affect customers' satisfaction in tea tourism. According the results of path analysis in table 3 indicate, all the variables have met the hypothesis acceptance requirements. Hence all the factors are statistically significant.

\section{Testing the Second Hypothesis:}

Resonance with brand, customers' feeling, and customer's judgment about brand, brand imagery, brand performance and brand salience affect customers' Loyalty in tea tourism. As the results of path analysis in Table 3 indicate, resonance with brand, customers' feeling, customers' judgment about brand, brand imagery, brand performance are having a significant effect on brand Loyalty with standard estimation and $\mathrm{P}$ value above recommended criteria. But Brand Salience has violate the criteria with a standard estimation of $0.04(<0.1)$ and with $\mathrm{P}$ value of 0.766 $(>0.05)$. Hence relationship of brand salience on brand loyalty is not significantly affected. 


\section{Testing the Third Hypothesis:}

Customer's' satisfaction and loyalty affect brand equity in tea tourism. As the results of path analysis in table 3 indicate, Brand loyalty and brand satisfaction are significantly affected on brand equity.

\section{Testing the Fourth Hypothesis:}

Resonance with brand, customers' feeling, and customer's judgment about brand, brand imagery, brand performance and brand salience affect brand equity in tea tourism. As the results of path analysis in table 4 indicate, brand salience, brand judgment, brand feeling, brand resonance are significant affected on brand equity with respect to the acceptance criteria of standard estimation above 0.1 and $\mathrm{P}$ value below 0.05 . But results reflect that brand performance and brand imagery are not significantly affected on brand equity since standard estimation is below 0.1 and $\mathrm{P}$ value higher than 0.05 .

\section{Discussion and Conclusion}

The main purpose of the present study is to propose a practical model of brand equity from the perspective of customers for gaining competitive advantage from customer satisfaction and loyalty. Therefore the study investigated the effect and relationship of the constructs of brand equity from the viewpoint of Keller (2008) on customers' satisfaction and loyalty in order to tests the hypothesis and confirmed the final model. An important finding of this study was when developing brand equity model for empowering tea tourism in Sri Lanka the customer satisfaction and customer loyalty have direct influence. Also there is a direct influence of Keller's brand equity dimensions towards the customer satisfaction and customer loyalty with various levels of significant.

In this study it was found that the relationship of brand salience towards customer loyalty does not significantly affect and the relationship between brand salience and customer loyalty, brand imagery, brand performance towards the brand equity were not significant and all other relationships were significant. But fit indices obtained for the conceptual model indicates a high level of validity of the estimated model, explaining the relationship among the variables. According the findings, it can be concluded that current strategies do not properly address the requirements of the potential tourists with respect to tea tourism in Sri Lanka.

This research conducted to propose a practical model to empower Sri Lanka as a tea tourism destination. According to the findings the tea tourism in Sri Lanka must consider all influential factors including customer loyalty and customer satisfaction together with the six dimensions of Keller's brand equity model in order to gain 
brand equity. The proposed model emphasized how marketers should design and implement the effective marketing programs to empower Sri Lanka as a tea tourism destination. In this way, the tea tourism in Sri Lanka can be positioned competitively in relation to competitors by attracting satisfied and loyal customers.

\section{References}

Aaker, D. A. (1991). Managing Brand Equity: Capitalizing on the value of a brand name. New York: Free Press.

Aaker, D. A. (1996). Building strong brands. New York: The Free Press.

Aghaei, M., Mosavi, M., Vahedi, E., \& Asadollahi, A. (2013). Developing Brand Equity Model Based on C.B.B.E Approach to Establish Customer Satisfaction and Loyalty in Tehran's chain stores. Journal of Basic and Applied Scientific Research, 3(7), 56965.

Bloemer, J., \& Odekerken-Schröder, G. (2002). Store satisfaction and store loyalty explained By customer- and store-related factors. Journal of Consumer Satisfaction, Dissatisfaction and Complaining Behavior, 15, 68-80.

Budiarty, A., Hawidjojo , A., \& jomahir, D. (2013). Brand Equity and Customer Satisfaction as the Mediation of Advertisement influence and the Service Quality to Loyalty the Passengers of International Flight at Garuda Indonesia Airlines”. Journal of Business and Management, 9(2).

Eakuru, N., \& Mat, N. (2008). The application of structural equation modeling (SEM) In determining the antecedents of customer loyalty in banks in South Thailand. The Business Review, Cambridge, 10(2), 129-139.

Faircloth, J., Capella, L., \& Alford, B. (n.d.). The effect of brand attitude and brand image on brand equity. Journal of Marketing Theory and Practice, 9(3), 61.

Farquhar, P. H. (1989). Managing brand equity. Marketing Research.

Kaiser, H. F. (1974). An index of factorial simplicity. Psychometrical.

Keller, K. (1998). Strategic Brand Management: Building, Measuring and Managing Brand Equity.

Keller, K. (2003). Strategic Brand Management. 2nd edition. Upper Saddle River.

Keller, K. L. (1993). Conceptualizing, measuring, and managing customer-based. Journal of Marketing, 57(1).

Keller, K. L. (2001). Building customer-based brand equity. Marketing.

Keller, K. (n.d.). Strategic Brand Management, Building, Measuring, and Managing Brand Equity. New Jersey: Pearson Education, Inc. 
Konecnik, M. \&. (2007). Customer-Based Brand Equity for a Destination. Annals of Tourism Research, 34(2), 400-421.

Kotler, P. (2005). According to Kotler: The World's Foremost Authority on Marketing. New York: AMACOM.

Kotler, P., \& Keller, K. (2009). Marketing Management. 13th Edition. New Jersey: Pearson.

Lance, C., Butts, M., \& Michels, L. (2006). The Sources of Four Commonly Reported Cutoff Criteria: What Did They Really Say? Organizational Research Methods. 9(2), 202-220.

Pike, S. (2010). Consumer-Based Brand Equity for Destinations: Practical DMO.

Pike, S., \& Bianchi, C. (2013). Destination brand equity for Australia: testing a model of CBBE in short-haul and long-haul markets. Journal of Hospitality \& Tourism Research, 20(10), 1-10.

PL, T. (2005). In the market but not of it: fair trade coffee and forest stewardship council certification as market-based social change World Development. 33(1), 129-147.

Reichheld, F., \& Sasser, J. (n.d.). Zero defections. Quality comes to Service. Harvard Business Review, 68(5), 105-11.

Reichheld, F., \& Teal, T. (1996). The Loyalty Effect. Boston: Harvard Business School Press.

Sarmad, Z., Bazargan, A., \& Hejazi , E. (1999). Research methods in behavioral sciences. 5rd edn. Tehran: Agah Publication.

Schumacker, R., \& Lomax, R. (1996). A Beginner's Guide to Structural Equation. New Jersey: Lawrence Erlbaum Associates, Publishers.

United Nations World Tourism Organization (UNWTO). (2014). Tourism Highlights”. Sri Lanka Tourism Development Authority. 